\title{
Western thuja (Thuja occidentalis L.): introduction in Siberia and use of nanoparticles in increasing the green cuttings rhizogenic activity
}

\author{
Valentina Bopp $^{1 *}$, Natalia Mistrartova ${ }^{1}$, and Yuri Gurevich ${ }^{2}$ \\ ${ }^{1}$ Krasnoyarsk state agrarian university, 660049, Krasnoyarsk, Mira Av., 90, Russia, \\ ${ }^{2}$ Krasnoyarsk scientific center of the Siberian branch of the Russian Academy of Sciences, 660036, \\ Krasnoyarsk, Akademgorodok Str., 50, Russia
}

\begin{abstract}
Western thuja (Thuja occidentalis L.) as a representative of evergreen coniferous species is of particular importance in the landscape gardening of urbanized territories in Siberia. An integral assessment of the introduction prospects based on the study of winter hardiness, regularity of shoots growth in height and other parameters showed that Western thuja in the soil and climatic conditions of Krasnoyarsk belongs to a promising taxon (86 points out of 105). For the purpose of widespread use of the introduced plant in the landscape gardeningpractice, a method for increasing the rooting capacity of Western thuja green cuttings is proposed. Soaking green cuttings in a solution of indolyl-3-acetic acid with citric acid and adding nanoparticles of biogenic ferrihydrite doped with aluminum increases the rhizogenesis of the cuttings material by $10-20 \%$.
\end{abstract}

\section{Introduction}

Evergreen gymnosperm tree of the cypress family (Cupressaceae) Western thuja (Thuja occidentalis L.) performs important functions in the ecology of urban ecosystems: it acts as a biofilter, allocates phytoncides, in addition, its decorative qualities determine the demand for creating recreational areas [1]. The representatives of coniferous species are in priorityfor landscape gardening of Siberian cities as the main producers of oxygen in the long winter period. The adaptive potential of Western thuja in the conditions of Krasnoyarsk was studied in order to expand regional plant biodiversity and use in green construction. The principles of propagation technology for garden and ornamental plants by cuttings are known [2-4]. However, for mass reproduction, it is usually necessary to adjust the technology for the selected plant species. For the widespread introduction of thuja in urban landscape gardening, it is also necessary to optimize the technology of its propagation [5-7].

* Corresponding author: vl kolesnikova@mail.ru 


\section{Materials and methods}

The assessment of Western thuja prospect was carried out by the method of integral evaluation [8] on the following indicators: growth strength, winter hardiness, resistance to pests and pathogens, decorative quality. The highest viability of plants according to this method is estimated at 105 points. It consists of the highest ratings for indicators: the degree of annual maturation of shoots -20 points, winter hardiness -25 , preservation of habitus -10 , shoot-forming capacity -5 , annual growth of shoots in height -5 , resistance to pests and diseases -5 , the ability to give germinating seeds -25 and the ability to reproduce by self-seeding-10 points. The 17-year-old and 5-year-old agespecimens of Western thuja, growing in the nursery of LLC «Garden center of the Agrarian university» (Krasnoyarsk) were used as model plants. To ensure the area of landscape gardening with thuja seedlings, an experiment to improve the technology of the croppropagationwas conducted. The influence of auxins and nanoparticles of biogenic ferrihydrite on rooting capacity of green cuttings was studied. Green cuttings obtaining was performed according to the methodology [9]. Cuttings harvested from the annual growth were soaked in a root formation stimulator in accordance with the scheme of the experiment, then planted in a film greenhouse in a peat-sand substrate. The necessary humidity of the air and soil was maintained by small-drop irrigation. Experiment options: 1-control, treatment of cuttings with indolyl-3-acetic acid (IAA); 2 -IAA + ferrihydrite (IAA + Feh); 3 -IAA + ferrihydrite doped with aluminum (IAA+ Feh_Al); 4 -IAA + ferrihydrite + citrate (IAA + Feh + citrate); 5 -IAA + ferrihydrite doped with aluminum + citrate (IAA + Feh_Al + citrate). Citric acid (citrate) was used to stabilize solutions of biogenic ferrihydrite nanoparticles in order to limit the aggregation of nanoparticles and loss of sedimentation stability of colloidal solutions. $100 \mathrm{ml}$ of colloidal solution of nanoparticles diluted 1:100 was injected into 1 liter of $0.07 \%$ IAA solution. The exposure time for cuttings treatment was 12 hours.

\section{Results and discussion}

Research has shown high resistance of the species to the soil and climate conditions of the region and to the conditions of urbanized environment. On average, the height of 17-yearold plants growing in the urban ecosystem is $357 \mathrm{~cm}$, and the crown diameters at the base of the stem and root neck are 120 and $9.1 \mathrm{~cm}$, respectively. The morphometric indicators of a 5-year-old plant are $104 \mathrm{~cm}$ in height, $53 \mathrm{~cm}$ in diameter of the crown at the base of the stem and $3.6 \mathrm{~cm}$ in diameter of the root neck. The average annual growth of the crown in height for plants of different ages was $21 \mathrm{~cm}$. Annual shoots fully mature.

The analysis of freezing of annual and perennial wood tissues on sections of thuja branches showed high resistance of plants to low temperatures in the winter period (Fig. 1). Tissue damage was noted in $1.2-1.3$ points on a 5-point scale. Pests and diseases on experimental plants were not recorded during the observation period. Decorative properties of thuja are expressed throughout the year.

The integral assessment of the introduction prospects allows to attributeWestern thuja to a promising taxon (86 points out of 105).

The experiment showed a high biological activity of nanoparticles when treating green cuttings of Western thuja (Fig. 2). The exposure of cuttings treatmentby IAA for 12 hours and more ensured the rooting of the cuttings material by about $80 \%$. The effectiveness of rooting of thuja cuttings under the influence of IAA in our experiment corresponds to the data presented by other researchers. In work [10] it was shown that when treating cuttings of gardenWesternthuja of Smaragdform, the stimulator heteroauxin with a processing exposure of 16 hours contributed to the rooting of $80 \%$ of cuttings. Studies [11] confirm the significant response of thuja cuttings to heteroauxinaction: without treatment with growth 
stimulants, rooting was $28 \%$ in the spherical form and $32 \%$ in the columnar form; treatment with a solution of indolyl-3-acetic acid at a concentration of $0.02 \mathrm{mg} / 1$ for 16-20 hours helped to increase the activity of root formation, 76 and $95 \%$ of cuttings were rooted, respectively.

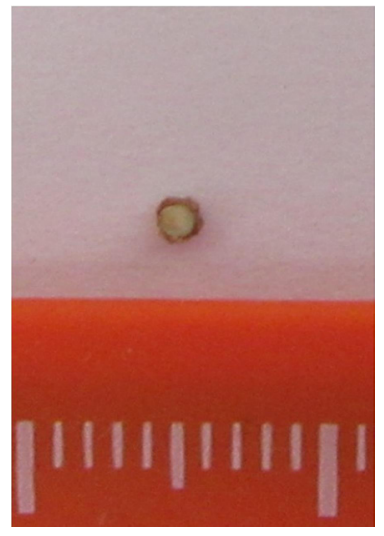

$a$

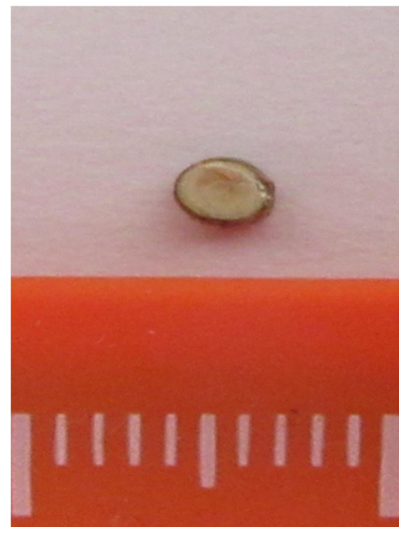

$b$

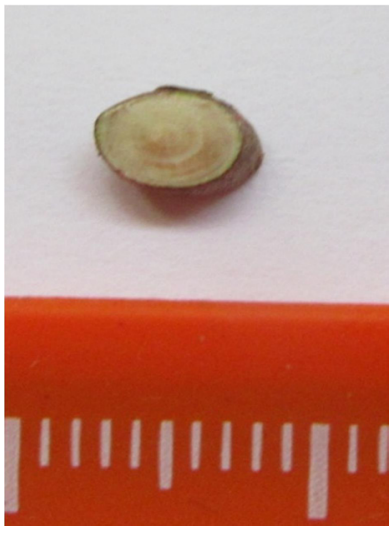

$c$

Fig. 1. The state of wood on sections of thuja branches. Age of shoots: $a-1$ year, $b-2$ yearsand $c-$ 3years

The high biological activity of nanoparticles is evidenced by statistically significant data on both their positive and negative impact on the rooting capacity of cuttings. Against the background of the IAA stimulating effect, nanoparticles $(F e h)$ reduced $(\mathrm{p}<0.05)$ rooting capacity from $80 \%$ in the control to $60 \%$ (Fig. 2). The decrease is due to a high concentration of nanoparticles. With a reduced dose of treatment, this effect, as observed later, disappears.

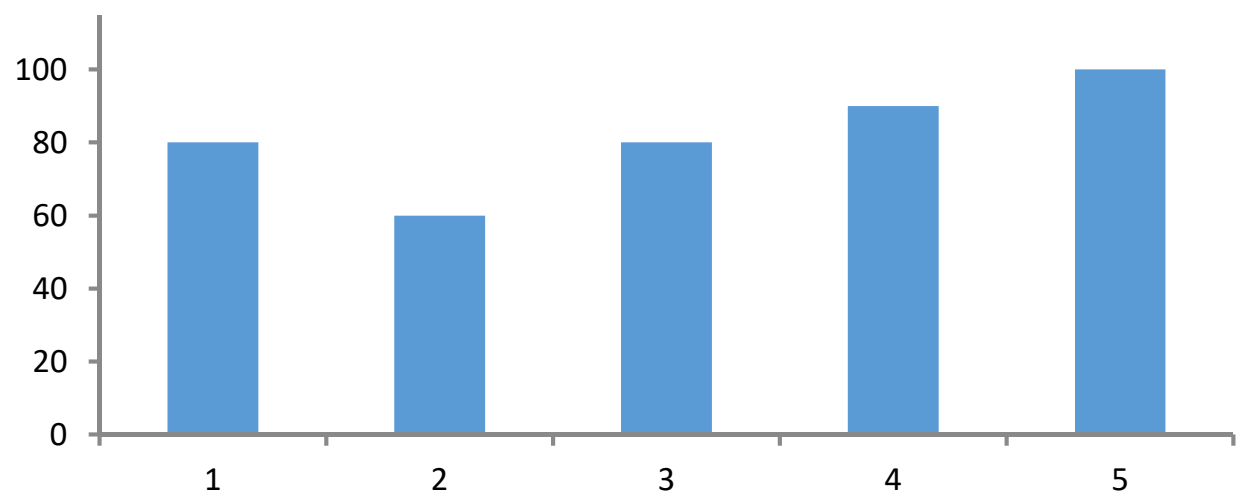

Fig. 2.Influence of biogenic ferrihydrite nanoparticles on the rooting capacity of Western thuja green cuttings. 1 -treatment of cuttings with IAA; 2 -IAA + Feh; 3 - IAA + Feh_Al; 4 - IAA + Feh + citrate; 5 - IAA+ Feh_Al + citrate

The inclusion of citric acid of biogenic ferrihydrite into colloidal solutions helped to increase the rooting capacity of cuttings. In the experiment with IAA + Feh + citrate, root formation is observed in $90 \%$ of the planted cuttings, and in the experiment with IAA+ Feh_Al + citrate, $100 \%$ of cuttings were rooted $(\mathrm{p}<0.05)$.

Rooting capacity is not the only and generalizing indicator of the technologyeffectiveness for obtaining seedlings from cuttings. The stimulating effect of 
nanoparticles on the development of the root system, in addition to biometric parameters, characterizes the formation of the aboveground part of thuja cuttings. As it is known, Western thuja plants develop very slowly at the first stages of ontogenesis. In our experiment, most of the control plants (IAA) formed an annual growth of 3-4 cm. Cuttings treated with IAA with the addition of biogenic ferrihydrite nanoparticles developed more actively. Growth of annual shoots varied in the range of $4-7 \mathrm{~cm}$.

The effectiveness of treatment of Western thuja cuttings with biogenic ferrihydrite nanoparticles is confirmed by the results of rooted cuttings rearing. Rooted cuttings were grown for 1 year in containers with a volume of 0.5 liters. The development of plants is demonstrated by the photo of typical samples of the obtained seedlings, shown in Fig. 3.

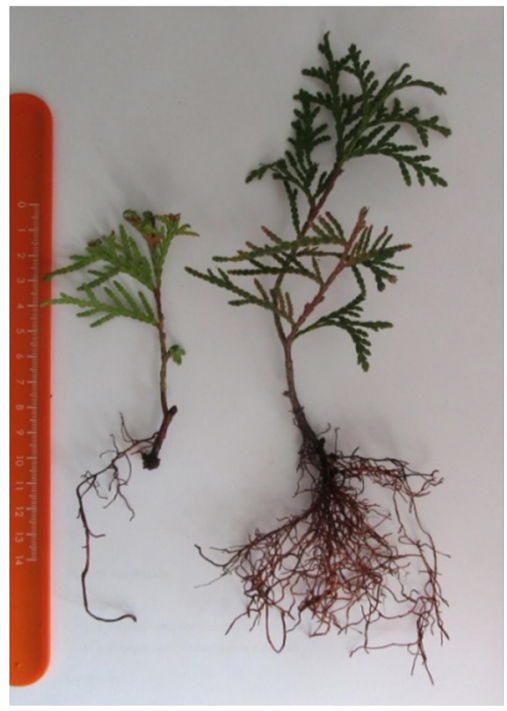

Fig. 3. Influence of auxin and nanoparticles of biogenic ferrihydrite on the development of rooted cuttings: on the left - the cutting treated with IAA, on the right - the cuttings treated with IAA + Feh composition

\section{Conclusions}

In general, the obtained data shows the prospects for the introduction of Western thuja in green construction of Eastern Siberia. The use of biogenic ferrihydrite nanoparticles is also promising in the thuja seedlings propagation technology. The effect of nanoparticles on induced rhizogenesis of green cuttings at the tested doses of their treatment was expressed in both stimulating and inhibiting rooting, depending on the modification of the particles. At the same time, solutions of nanoparticles used for rooting cuttings contributed to the better development of annual thuja plants.

\section{References}

1. R. A. Ivanov, E. Y. Matvienko, Advances in modern natural science, 8, 122 (2014)

2. D. V. Kolbanov, Ye. O. Legerova, I. I. Donskaya, A.V. Batulev, S. A. Chaykun, V. V. Demidchik Biotechnological methods in conservation of biodiversity and plant breeding,in Proceeding of the International Scientific Conference, 12-14 Avgust, 2011, Minsk, Belarus (2014) 
3. N. A. Mistratova, V. L Bopp, KSAU Bulletin, 2, 3-9 (2017)

4. N. A. Mistratova, V. L. Bopp, Flora of Asian Russia, 4, 80-82 (2016)

5. C. Chong, Compost science and Utilization, 1, 29-35 (2000)

6. M. Maier, P. Salas, M. Jonas, H. Saskova, M. B. Matraimov Mendel and Bioclimatology, 210-214 (2016)

7. M. F. Moseschenko, A. Kh. Trifonova, V. E. Zaveryukha, T. I. Eshchenko. Fundamentals of scientific research in agronomy (Moscow, Russia, 1996)

8. P. I. Lapin, S. V. Sidneva Introduction of woody plants (Moscow,Main Botanical garden of the Russian Academy of Sciences of USSR, 1973)

9. Z. Ya. Ivanova Biological bases and techniques of vegetative propagation of woody plants by stem cuttings (Kiev, Ukraine, 1982)

10. N. V. Nilov, S. A. Khasbulatov, S. S. Chukuridi Scientific support of the agroindustrial complex, in Proceeding on the materials of the IX all-Russian conference of young scientists. Publishinghouse of Kuban state agrarian university, 16 November, 2015, Krasnodar (2015)

11. E. V. Abdullayeva, A. R. Ramazanova, Subtropical and decorative gardening. 45, 156$159(2011)$ 